\title{
Diversity of fungal flora in raw milk from the Italian Alps in relation to pasture altitude
}

\author{
Simona Panelli, Eva Brambati, Cesare Bonacina and Maria Feligini
}

\begin{abstract}
The present paper explores the diversity of mycobiota inhabiting raw milk sampled at different altitudes (1400 m, 1800 m, 2200 m) from cows grazing Alpine pastures of Valle d'Aosta (North-Western Italian Alps). To this aim, multilocus sequencing was performed at barcodes commonly used for fungal identification (ITS1, D1/D2 domains of the $26 \mathrm{~S}$ rRNA gene, and part of the $\beta$-tubulin gene). A total of 31 species were detected, most of them yeasts, followed by moulds and by 2 sequences of macroscopic fungi. Several yeasts and moulds were well-characterized inhabitants of the dairy environment, known to positively contribute to cheesemaking. Among these, Candida was the most represented genus with a tendency to cluster at the highest altitudes ( 6 over 8 observations at $\geq 1800$ $\mathrm{m})$, and Kluyveromyces marxianus the most abundant single species, retrieved at all altitudes. The environmental ascomycetous Atrotorquata lineata, never put in relation with food nor described outside North-America, was another species among those most frequently retrieved and was detected in 6 milks at 1400 and $1800 \mathrm{~m}$. The remaining fungi, in general never reported in milk, were mostly environmental. Many of them resulted associated with plants as pathogens or symbionts. Finally, the highest sampled altitude yielded a significant fungal diversity (17 species). This work enlarges the knowledge of fungal consortia inhabiting raw milk and introduces microbial ecology among the altitude-dependent factors, in the composition of Alpine pastures, with the potential of shaping the properties of milks and cheeses, together with the already described physical, chemical and botanical variables.

Keywords: Raw milk; Yeasts; Moulds; Alpine pastures; Barcodes
\end{abstract}

\section{Introduction}

In all cheeses made from raw milk, the contribution to flavouring of factors linked to the area of production is prominent. The specific environmental conditions (e.g., those of valleys and Alpine pastures) often linked to the use of traditional cheesemaking processes, define cheese aroma and texture by determining the unique features of the raw milk (Martin et al. 2005). These comprehend (i) chemical characteristics and presence of specific molecules (e.g., carotenes, terpenes) that significantly depend on grass botanical composition and on geographical variants as altitude (Buchin et al. 1999); (ii) composition in natural micro- and mycobiota. The contribution to cheese homogeneity of autochthonous lactic micro- and mycoflora is deep (Beresford et al. 2001): for this reason, production regulations currently allow the exclusive addition to raw milk of bacterial strains

\footnotetext{
* Correspondence: simona.panelli@istitutospallanzani.it

Istituto Sperimentale Italiano Lazzaro Spallanzani, Località La Quercia, Rivolta d'Adda (Cremona) 26027, Italy
}

isolated in the area of production. Therefore, the description of the microbial communities inhabiting raw milk and cheeses which production is allowed only within well-defined geographical areas is particularly relevant for dealing with product quality features and authenticity assurance. These are relevant points because the production of raw milk cheeses is growing, and consumers more and more seek organic foods and traditional sensory characteristics (Laurenčic et al. 2008).

Bacterial species inhabiting raw milk have been recently reported by our group (Giannino et al. 2009) in a context where the microbial diversity characterizing traditional raw milk cheeses and the milks used for their production is still largely uncharacterized. This is especially true for eukaryotic microorganisms, whose importance is being increasingly acknowledged in spite of a continuously evolving classification. They in fact play a synergistic role by excreting growth factors as vitamins, and by priming the growth of acid-sensitive bacteria thanks to their ability of metabolizing lactate, which

\section{Springer}


causes a shift of the pH towards neutrality (Butinar et al. 2005). Fungal flora is also able of generating components of aroma (e.g., amino acids, fatty acids, esters) that significantly contribute to flavour (Lund et al. 1995; Vasdinyei \& Deak 2003). On the other hand, mycobiota can act as spoilage organisms that contribute to the deterioration of sensorial properties (Fleet 2007), or pose relevant medical problems, as in the case of micotoxins produced by moulds (Filtenborg et al. 1996).

In the present paper, the mycobiota of cow raw milk from highaltitude pastures used for Fontina cheese production are characterized using DNA barcoding. Samples come from several Alpine valleys within Valle d'Aosta region (Italian Alps) and are representative of different altitudes (altitude equal to or higher than 1400 $\mathrm{m}$ above sea level).

Fontina is a PDO cheese exclusively produced in Valle d'Aosta region under the Commission Regulation 1107 / $96 / \mathrm{EC}$ and later amendments. It is a semi-cooked, smear-rind cheese produced using full cream raw milk derived from a single milking of cows belonging exclusively to the autochthonous Valdostana breed.

DNA barcoding is the culture-independent approach considered as the election technique for fungal species identification (Begerow et al. 2010; Giraud et al. 2010). The barcodes considered in the present paper are both ribosomal (the internal transcribed spacer 1, ITS1, between the 18S rRNA and 5.8 rRNA genes, and the variable D1/D2 domains at the $5^{\prime}$ end of the $26 \mathrm{~S}$ rRNA gene) and non-ribosomal ( $\beta$-tubulin, TUB). Barcoding was performed on DNA directly extracted from milk without intermediate culturing and generation of fungal isolates to avoid disadvantages inherently linked to this step.

\section{Methods \\ Sampling}

A total of 40 bulk raw milks were collected during summer (June-July-August) from 1400 m, 1800 m, 2200 m Alpine pastures across Valle d'Aosta region (NorthWestern Italian Alps). In addition, 9 raw milks from different herds were sampled at an altitude $<700 \mathrm{~m}$ (bottom of valleys). After sampling, milk was frozen at $-20^{\circ} \mathrm{C}$.

\section{DNA extraction}

DNA was isolated from all samples by phenol-chloroform extraction. Raw milks ( $40 \mathrm{ml}$-each) were thawed at $37^{\circ} \mathrm{C}$ for $2 \mathrm{~h}$ and centrifuged at $1,000 \times g$ for $10 \mathrm{~min}$ at $4^{\circ} \mathrm{C}$. Pellets were picked up with $1 \mathrm{ml}$ lysis buffer (10 mM Tris- $\mathrm{HCl} \mathrm{pH} 7.5,1 \mathrm{mM}$ EDTA, $51 \mathrm{mM} \mathrm{NaCl}$, $2 \mathrm{mg} / \mathrm{ml} \mathrm{SDS}$ ) and digested with $50 \mathrm{mg}$ proteinase K (Fermentas Life Sciences, Burlington, ON, Canada) on a linear shaker overnight at $42^{\circ} \mathrm{C}$. After the addition of $50 \mathrm{mg}$ lysozyme solution (Sigma-Aldrich, St. Louis, Mo.,
USA), samples were incubated for $1 \mathrm{~h}$ at $37^{\circ} \mathrm{C} .1 \mathrm{ml}$ of phenol was added to the digested suspensions, that were then mixed for $10 \mathrm{~min}$ and centrifuged at $11,000 \times g$ for $10 \mathrm{~min}$ at $4^{\circ} \mathrm{C}$. Supernatants were transferred in sterile tubes and solvent extraction was repeated 3 more times using $1: 1$ phenol-chloroform mix. After addition of 0.1 volumes sodium acetate $(\mathrm{pH} 5.2)$ and 2.5 volumes ethanol, samples were kept at $-20^{\circ} \mathrm{C}$ overnight. DNA was pelleted by centrifugation $\left(11,000 \times g\right.$ for $20 \mathrm{~min}$ at $\left.4^{\circ} \mathrm{C}\right)$ and suspended in $50 \mu \mathrm{l}$ of double distilled sterile water. Its concentration and purity were assessed using a NanoDrop ${ }^{\circ}$ ND-1000 spectrophotometer (NanoDrop Technologies, Inc., Wilmington, DE, USA).

\section{Barcodes amplification}

All PCR reactions were set up in a $50 \mu$ volume containing $10 \mathrm{mM}$ Tris- $\mathrm{HCl} \mathrm{pH} 8.3,50 \mathrm{mM} \mathrm{KCl}, 0.2$ $\mathrm{mM}$ dNTPs, $2.5 \mathrm{mM} \mathrm{MgCl} 2,1 \mu \mathrm{M}$ of each primer, $3.5 \mathrm{U}$ AmpliTaq Gold (Life Technologies, Foster City, CA), and about $50 \mathrm{ng}$ template genomic DNA.

Primers used in this study are the following: (i) for the ITS1 barcode: forward primer ITS1 (TCCGTAGGTGAA CCTGCGG), reverse primer ITS2 (GCTGCGTTCTT CATCGATGC) that give PCR products of variable sizes in different species (White et al. 1990); (ii) for the D1/ D2 barcode: forward primer NL1 (GCATATCAATAAG CGGAGGAAA), reverse primer NL4 (GGTCCGTGTTT CAAGACGG) that give PCR products around $600 \mathrm{bp}$, with slight species-specific variations (Kurtzmann \& Robnett 1997); (iii) for the TUB barcode: forward primer BT2a (GGTAACCAAATCGGTGCTGCTTTC), reverse primer BT2b (ACCCTCAGTGTAGTGACCCTTGGC) that give amplicons around 500 bp (Glass \& Donaldson 1995).

Amplifications were performed on a Bioer LifePro thermal cycler (Bioer Technology Co, Ltd, Tokyo, Japan) according to the following cycling program: initial denaturation step $\left(95^{\circ} \mathrm{C} 10 \mathrm{~min}\right), 35$ cycles at $94^{\circ} \mathrm{C} 30 \mathrm{~s}$, $56^{\circ} \mathrm{C} 30 \mathrm{~s}, 72^{\circ} \mathrm{C} 40 \mathrm{~s}$, final elongation $\left(72^{\circ} \mathrm{C} 10 \mathrm{~min}\right)$. Only for D1/D2 the annealing was $60^{\circ} \mathrm{C} 1 \mathrm{~min}$, the extension $72^{\circ} \mathrm{C} 1 \mathrm{~min}$ and the number of cycles 30. Samples were analyzed using all three barcodes. DNA from milk sampled at bottom of valleys were amplified at the D1/D2 barcode.

\section{Cloning and sequencing}

PCR products were visualized on $2 \% \mathrm{TBE}$ agarose gels. Amplicons were either sequenced directly on both strands using an ABI PRISM $3130 \times 1$ automated DNA sequencer (Life Technologies) or, in the case of faint or multiple bands, subjected to an intermediate cloning step using the TOPO ${ }^{-}$TA cloning kit (Life Technologies). In detail: $3 \mu \mathrm{l}$ of PCR products were ligated into the $\mathrm{pCR}^{\circ} 4-\mathrm{TOPO}^{\circ}$ (Life Technologies). Recombinant plasmids were used to transform Escherichia coli Top10 
competent cells according to the manufacturer's protocol. After plating onto kanamycin-LB plates, transformant clones were picked and subjected to colony PCR using M13 primers (F: TTTCCCAGTCACGACGTT GTA; R: TTGTCAGCGGATAACAATTTC). For each cloning reaction, amplicons representing recombinant inserts of the expected molecular weight were purified using Agencourt AMPure XP-PCR purification beads (Beckam Coulter, Brea, CA) and sequenced on an ABI PRISM $3130 \times 1$ automated DNA sequencer (Life Technologies) using T7 primer (TAATACGACTCACTATAG GG). Three recombinant plasmids were normally sequenced per cloning reaction. In the case of multiple bands, this number was raised up to 10 .

\section{Sequence analysis}

Electropherograms were visually inspected and manually edited for quality using the Bioedit program (http:// www.mbio.ncsu.edu/BioEdit/BioEdit.html) (Hall 1999). Sequences were then compared to the GenBank database by means of BLAST searches (www.ncbi.nlm.nih. gov/BLAST). When necessary, sequences were aligned using the ClustalW algorithm implemented in the Mega5 software (Kumar et al. 2004). RNA secondary structures of domains D1/D2 encoded by 26S rRNA genes with different in-del polymorphisms were predicted using the following web servers: (i) mfold web $\mathrm{v}$ 2.3 (http://mfold.rna.albany.edu), with the default parameters, except for the temperature, that was set at $25^{\circ} \mathrm{C}$; (ii) RNAalifold (http://rna.tbi.univie.ac.at/cgi-bin/ RNAalifold.cgi) that predicts the consensus secondary structure of aligned sequences.

\section{Results}

\section{Fungal diversity in relation to altitude}

Table 1 reports the list of the fungal species detected at the various altitudes by multilocus gene sequencing. All the sequences not resolved at least at the genus level have been omitted as well as the cases that yielded as only hit an homology with "unidentified" or "uncultured" fungi, without any taxonomic details. Other non included results comprehend a conspicuous number of bacterial, plant and metazoan species, consistently identified by all the barcodes, either in the case of direct sequencing and when sequencing cloned amplicons. Some of these sequences are mentioned in the Discussion.

A total of 31 fungal species have been retrieved, in addition to 5 genera not resolved at the species level, and a new sequence deposited in the GenBank under the Acc. No. KC954152. This sequence has been detected in a milk sampled at $1400 \mathrm{~m}$ and its best hit is the soil fungus JQ311712 (87\% homology).

The $1400 \mathrm{~m}$ class yielded 10 species (Table 1) plus 1 unresolved genus and the new sequence KC954152, whereas at $1800 \mathrm{~m} 8$ different species and 1 unresolved genus were observed. For milks sampled at $2200 \mathrm{~m}, 17$ species and 3 genera as shown in Table 1 were obtained.

The most represented genus is Candida, with 6 different species, the majority of which (6 over 8 observations) retrieved at altitudes $\geq 1800 \mathrm{~m}$. The genera Exophiala, Aspergillus and Pichia are respectively represented by 2 species (E. pisciphila, E. dermatitidis, $A$. penicilloides, A. versicolor, P. membranifaciens, P. subpel liculosa) without an altitude-specific segregation.

Species found at various altitudes comprehend Kluyveromyces marxianus, that resulted widespread as well as Debaryomyces hansenii (except for the $1800 \mathrm{~m}$ class). Exophiala pisciphila and Atrotorquata lineata characterized the intermediate classes (1400 and 1800 m) while Candida deformans was sampled at the highest altitudes (1800 and $2200 \mathrm{~m}$ ).

In general, the identified species are mainly yeasts, followed by moulds and by 2 species of macroscopic fungi (signaled in Table 1).

The analysis of the D1/D2 domains of 9 raw milks sampled from herds at bottom of valleys $(<700 \mathrm{~m})$ allowed to detect 7 species (Table 1). Four of them are shared with Alpine pastures: K. marxianus, D. hansenii, Galactomyces geotrichum, C. pararugosa.

\section{Fungal species identified by the various barcodes}

Table 2 reports the list of the species detected by each of the 3 barcodes. A total of 21 species and 5 unresolved genera have been identified by the ITS1 barcode and 13 species by $\mathrm{D} 1 / \mathrm{D} 2$, in addition to the new sequence KC954152. Finally, TUB discriminated 3 species.

Six species were identified by both ribosomal barcodes. In detail: $K$. marxianus, that resulted among the most abundant species, has been observed 4 times by ITS1 and 8 times by D1/D2 that also allowed to distinguish 3 sequence variants, characterized by in-del polymorphisms at the 26S rRNA locus as detailed in section 3.3. Other species identified by both barcodes comprehend, in order of abundance: D. hansenii, G. geotrichum, C. pararugosa, C. catenulata, C. glaebosa.

The ascomycetous Atrotorquata lineata is the most abundant species retrieved by a single barcode (ITS1), with a total of 6 observations.

\section{Three variants of $K$. marxianus sequences with in-del polymorphisms in domains D1/D2}

Direct sequencing of 7 PCR products and of one cloned amplicon for the D1/D2 barcode revealed the presence of 3 variant sequences for $K$. marxianus carrying in-del polymorphisms in milk sampled at different altitudes. The first variant, 100\% homologous to HQ436414 (Table 2), was retrieved in 2 milks sampled at $2200 \mathrm{~m}$ and in 1 at $1800 \mathrm{~m}$. The second sequence $(100 \%$ 
Table 1 Fungal species identified in raw bulk milk sampled at various altitudes

\begin{tabular}{|c|c|c|c|c|}
\hline Altitude & $\begin{array}{l}\text { Milks from } \\
\text { individual } \\
\text { pastures (n) }\end{array}$ & Identity & Source and significance & References \\
\hline \multirow[t]{12}{*}{1400} & 5 & $\begin{array}{c}\text { Kluyveromyces } \\
\text { marxianus }\end{array}$ & Raw milk, yogurt, cheese. Potential probiotic & $\begin{array}{c}\text { (Hatoum et al. 2012; Jacques \& } \\
\text { Casaregola 2008; Lane \& Morrisey 2009) }\end{array}$ \\
\hline & & $\begin{array}{l}\text { Debaryomyces } \\
\text { hansenii }\end{array}$ & $\begin{array}{c}\text { Marine environment, brine, cheese, floor, } \\
\text { walls, hands and equipments in cheese } \\
\text { plants. Potential probiotic }\end{array}$ & $\begin{array}{l}\text { (Hatoum et al. 2012; Jacques \& } \\
\text { Casaregola 2008; Welthagen \& Viljoen 1998) }\end{array}$ \\
\hline & & $\begin{array}{l}\text { Galactomyces } \\
\text { geotrichum }\end{array}$ & Soil, insects, milk, cheese. Plant pathogen & cbs.knawl.nl \\
\hline & & $\begin{array}{l}\text { Atrotorquata } \\
\text { lineata }\end{array}$ & Associated to salt-tolerant plants & (Kohlmeyer \& Volkmann-Kohlmeyer 1993) \\
\hline & & $\begin{array}{l}\text { Aspergillus } \\
\text { penicilloides }\end{array}$ & $\begin{array}{l}\text { House dust, food, water. Produces } \\
\text { potential antibiotics }\end{array}$ & (Itabashi et al. 2006) \\
\hline & & $\begin{array}{l}\text { Colletothricum } \\
\text { gloesporioides }\end{array}$ & Soil. Pathogen for crops & (Cai et al. 2009) \\
\hline & & $\begin{array}{l}\text { Pichia } \\
\text { membranifaciens }\end{array}$ & $\begin{array}{l}\text { Cheese, wine, brines, spoiled food, } \\
\text { sugar cane, tequila, plants }\end{array}$ & $\begin{array}{c}\text { (Corbo et al. 2001; Jacques \& Casaregola } \\
\text { 2008) }\end{array}$ \\
\hline & & $\begin{array}{l}\text { Exophiala } \\
\text { pisciphila }\end{array}$ & Soil, water, plants, decaying wood material & (Figel et al. 2013) \\
\hline & & $\begin{array}{l}\text { Ophiocordyceps } \\
\text { oxycephala }\end{array}$ & Entomopathogen for wasps & cordyceps.us/node/5820 \\
\hline & & Alternaria solani & Soil, roots. Pathogen for tomatoes and potatoes & (Ai et al. 2012) \\
\hline & & Phoma spp. & Air, spoiled vacuum-packaged cheese & (Hocking \& Faedo 1992) \\
\hline & & $\begin{array}{l}\text { Unknown } \\
\text { fungus }\end{array}$ & Soil & Acc.No. JQ311712 \\
\hline \multirow[t]{9}{*}{1800} & 11 & $\begin{array}{l}\text { Kluyveromyces } \\
\text { marxianus }\end{array}$ & Raw milk, yogurt, cheese. Potential probiotic & $\begin{array}{l}\text { (Hatoum et al. 2012; Jacques \& } \\
\text { Casaregola 2008; Lane \& Morrisey 2009) }\end{array}$ \\
\hline & & $\begin{array}{l}\text { Atrotorquata } \\
\quad \text { lineata }\end{array}$ & Associated to salt-tolerant plants & (Kohlmeyer \& Volkmann-Kohlmeyer 1993) \\
\hline & & $\begin{array}{l}\text { Candida } \\
\text { deformans }\end{array}$ & $\begin{array}{l}\text { Insects, preserved fish, cured ham, } \\
\text { yoghurt, spoiled food }\end{array}$ & (Knutsen et al. 2007) \\
\hline & & $\begin{array}{l}\text { Candida } \\
\text { glaebosa }\end{array}$ & $\begin{array}{l}\text { Marine- and fresh-water, soil, wood, } \\
\text { wine must, blue cheese, raw milk }\end{array}$ & mushroomobserver.org \\
\hline & & Wallemia sebi & Dust, food, mural paintings & Acc.No. AM159621 \\
\hline & & $\begin{array}{l}\text { Peniophora } \\
\text { cinerea }\end{array}$ & Wood & (Chamuris 1991) \\
\hline & & $\begin{array}{l}\text { Euroticum } \\
\text { amstelodami }\end{array}$ & $\begin{array}{l}\text { Soil, dust, indoor environments. } \\
\text { Opportunistic pathogen }\end{array}$ & (Rakeman et al. 2005) \\
\hline & & $\begin{array}{l}\text { Exophiala } \\
\text { pisciphila }\end{array}$ & $\begin{array}{l}\text { Saprophite found in soil, water, } \\
\text { plants, decaying wood material }\end{array}$ & (Figel et al. 2013) \\
\hline & & $\begin{array}{l}\text { Trichosporon } \\
\text { spp. }\end{array}$ & Cheese & (Borelli et al. 2006; Vasdinyei \& Deak 2003) \\
\hline \multirow[t]{5}{*}{2200} & 14 & $\begin{array}{l}\text { Kluyveromyces } \\
\text { marxianus }\end{array}$ & Raw milk, yogurt, cheese. Potential probiotic & $\begin{array}{c}\text { (Hatoum et al. 2012; Jacques \& } \\
\text { Casaregola 2008; Lane \& Morrisey 2009) }\end{array}$ \\
\hline & & $\begin{array}{l}\text { Debaryomyces } \\
\text { hansenii }\end{array}$ & $\begin{array}{l}\text { Marine environment, brine, cheese, } \\
\text { floor, walls, hands and equipments in cheese } \\
\text { plants. Potential probiotic }\end{array}$ & $\begin{array}{l}\text { (Hatoum et al. 2012; Jacques \& } \\
\text { Casaregola 2008; Welthagen \& Viljoen 1998) }\end{array}$ \\
\hline & & $\begin{array}{l}\text { Candida } \\
\text { deformans }\end{array}$ & $\begin{array}{l}\text { Insects, preserved fish, cured ham, } \\
\text { yoghurt, spoiled food }\end{array}$ & (Knutsen et al. 2007) \\
\hline & & $\begin{array}{l}\text { Candida } \\
\text { catenulata }\end{array}$ & $\begin{array}{c}\text { Cheese, floor and walls of cheese plants. } \\
\text { Agent of fungemia }\end{array}$ & $\begin{array}{c}\text { (Larsson \& Örstadius 2008; Jacques \& } \\
\text { Casaregola 2008; Radosavljevic et al. 1999; } \\
\text { Welthagen \& Viljoen 1998) }\end{array}$ \\
\hline & & $\begin{array}{l}\text { Candida } \\
\text { pararugosa }\end{array}$ & $\begin{array}{l}\text { Widespread in the environment, milk } \\
\text { and cheese. Opportunistic pathogen. }\end{array}$ & $\begin{array}{c}\text { (Giammarco et al. 2004; Nakagawa et al. } \\
\text { 2004), Acc No GQ458032 }\end{array}$ \\
\hline
\end{tabular}


Table 1 Fungal species identified in raw bulk milk sampled at various altitudes (Continued)

\begin{tabular}{|c|c|c|c|c|}
\hline & & $\begin{array}{l}\text { Candida } \\
\text { incospicua }\end{array}$ & $\begin{array}{c}\text { Beer, milk and cheese, animal feces. Opportunistic } \\
\text { pathogen }\end{array}$ & (Borelli et al. 2006) \\
\hline & & $\begin{array}{l}\text { Aspergillus } \\
\text { versicolor }\end{array}$ & $\begin{array}{l}\text { Plants, cheese, marine water, starchy food. } \\
\text { Opportunistic pathogen }\end{array}$ & (Torres-Rodríguez et al. 1998) \\
\hline & & $\begin{array}{c}\text { Pichia } \\
\text { subpelliculosa }\end{array}$ & Raw milk cheese, fermented olives & (Borelli et al. 2006), Acc No JQ419793 \\
\hline & & $\begin{array}{l}\text { Galactomyces } \\
\text { geotrichum }\end{array}$ & Soil, insects, milk, cheese. Plant pathogen & cbs.knawl.nl \\
\hline & & $\begin{array}{l}\text { Torulaspora } \\
\text { delbrueckii }\end{array}$ & $\begin{array}{l}\text { Raw milk, cheese, equipment in cheese plants. } \\
\text { Potential spoilage yeast. Potential probiotic }\end{array}$ & $\begin{array}{c}\text { (Borelli et al. 2006; Hatoum et al. 2012; } \\
\text { Jacques \& Casaregola 2008; Welthagen \& } \\
\text { Viljoen 1998) }\end{array}$ \\
\hline & & $\begin{array}{l}\text { Psathyrella } \\
\text { lutensis }^{a}\end{array}$ & Soil, wood, animal feces & (Larsson \& Örstadius 2008) \\
\hline & & $\begin{array}{l}\text { Macrophomina } \\
\text { phaseolina }\end{array}$ & Soil. Plant pathogen & Acc No. GU046904 \\
\hline & & $\begin{array}{l}\text { Funneliformis } \\
\text { mosseae }\end{array}$ & Mutualistic symbiont of plants. & Acc No. JN847444 tolweb.org \\
\hline & & $\begin{array}{l}\text { Yarrowia } \\
\text { lipolytica }\end{array}$ & Food, cheese, drinks. Potential probiotic & $\begin{array}{c}\text { (Hatoum et al. 2012; Jacques \& Casaregola } \\
\text { 2008) }\end{array}$ \\
\hline & & $\begin{array}{l}\text { Clavispora } \\
\text { lusitaniae }\end{array}$ & $\begin{array}{l}\text { Equipment and hands in cheese plants, } \\
\text { fruit, cheese. Opportunistic pathogen. }\end{array}$ & $\begin{array}{c}\text { (El-Sharoud et al. 2009; Jacques \& Casaregola } \\
\text { 2008; Welthagen \& Viljoen 1998) }\end{array}$ \\
\hline & & $\begin{array}{l}\text { Pachyphloeus } \\
\text { virescens }^{a}\end{array}$ & Soil, truffle & Acc No EU543198 \\
\hline & & $\begin{array}{l}\text { Peronospora } \\
\text { pulveracea }\end{array}$ & Water. Plant pathogen & (Göker et al. 2009) \\
\hline & & $\begin{array}{l}\text { Galactomyces } \\
\text { spp. }\end{array}$ & Soil, fruit, milk, cream, cheese & cbs.knawl.nl \\
\hline & & $\begin{array}{l}\text { Cryptococcus } \\
\text { spp. }\end{array}$ & Air, cheese & (Welthagen \& Viljoen 1998) \\
\hline & & $\begin{array}{l}\text { Rhodotorula } \\
\text { spp. }\end{array}$ & See sediments, air, cheese & (Welthagen \& Viljoen 1999) \\
\hline \multirow[t]{7}{*}{$<700 m$} & 9 & $\begin{array}{l}\text { Kluyveromyces } \\
\text { marxianus }\end{array}$ & Raw milk, yogurt, cheese. Potential probiotic & $\begin{array}{c}\text { (Hatoum et al. 2012; Jacques \& Casaregola } \\
\text { 2008; Lane \& Morrisey 2009) }\end{array}$ \\
\hline & & $\begin{array}{l}\text { Debaryomyces } \\
\text { hansenii }\end{array}$ & $\begin{array}{c}\text { Marine environment, brine, cheese, floor, walls, } \\
\text { hands and equipments in cheese plants. Potential } \\
\text { probiotic }\end{array}$ & $\begin{array}{l}\text { (Hatoum et al. 2012; Jacques \& Casaregola } \\
\text { 2008; Welthagen \& Viljoen 1998) }\end{array}$ \\
\hline & & $\begin{array}{l}\text { Candida } \\
\text { pararugosa }\end{array}$ & $\begin{array}{l}\text { Widespread in the environment, milk and cheese. } \\
\text { Opportunistic pathogen. }\end{array}$ & $\begin{array}{c}\text { (Giammarco et al. 2004; Nakagawa et al. } \\
\text { 2004), Acc No GQ458032 }\end{array}$ \\
\hline & & $\begin{array}{l}\text { Candida } \\
\text { parapsilopsis }\end{array}$ & Raw milk cheese & (Borelli et al. 2006) \\
\hline & & $\begin{array}{l}\text { Galactomyces } \\
\text { geotrichum }\end{array}$ & Soil, insects, milk, cheese. Plant pathogen & cbs.knawl.nl \\
\hline & & $\begin{array}{l}\text { Exophiala } \\
\text { dermatitidis }\end{array}$ & $\begin{array}{l}\text { Forest, water, wet indoor environments. } \\
\text { Cutaneous infections. Neurotrophic }\end{array}$ & (Heinrich et al. 2013; Sudhadham et al. 2008) \\
\hline & & $\begin{array}{l}\text { Priceomyces } \\
\text { carsonii }\end{array}$ & Fermenting red wine & Acc No. JX456534 \\
\hline
\end{tabular}

\footnotetext{
${ }^{\mathrm{a}}$ Macroscopic fungus.
}

homology with HQ396523) characterized 1 sample at $2200 \mathrm{~m}$ and 1 at $1800 \mathrm{~m}$, while the last one $(100 \%$ homology with FJ896141) was found in 2 milks sampled at the bottom of valleys. The first group of sequences is characterized by the deletion of $2 \mathrm{nu}$ cleotides ( $G$ and A, respectively at positions 779 and 784 of HQ396523), while the third set has one deleted $\mathrm{T}$ as compared to groups 1 and 2 (see position 772 of HQ396523). These polymorphisms fall in the 5 ' end of the region amplified by primers NL1/ NL4 corresponding to the D1 domain of the $26 \mathrm{~S}$ rRNA (De Rijk et al. 1997). Predictions performed either on the single sequences and on the consensus derived from the alignment showed that the retrieved 
Table 2 Fungal species detected by the different barcodes

\begin{tabular}{|c|c|c|c|c|}
\hline Barcode & Identity & Number of milks & $\%$ similarity & Accession number \\
\hline \multirow[t]{26}{*}{ ITS1 } & Kluyveromyces marxianus & 4 & 100 & HE650691 \\
\hline & Debaryomyces hansenii & 1 & 100 & JQ912667 \\
\hline & Galactomyces geotrichum & 2 & 100 & AJ876893 \\
\hline & Candida pararugosa & 2 & 98 & GQ458032 \\
\hline & Candida catenulata & 2 & 100 & GU246267 \\
\hline & Candida glaebosa & 1 & 98 & JQ697543 \\
\hline & Candida deformans & 3 & 99 & AM279256 \\
\hline & Candida incospicua & 1 & 99 & AB179767 \\
\hline & Atrotorquata lineata & 6 & 100 & AF009807 \\
\hline & Aspergillus versicolor & 1 & 99 & $J \times 526463$ \\
\hline & Aspergillus penicilloides & 1 & 100 & DQ336711 \\
\hline & Psathyrella lutensis & 1 & 97 & DQ389685 \\
\hline & Macrophomina phaseolina & 1 & 99 & GU046904 \\
\hline & Funneliformis mosseae & 1 & 100 & JN847444 \\
\hline & Yarrowia lipolytica & 1 & 100 & AF335962 \\
\hline & Clavispora lusitanae & 1 & 99 & EF151449 \\
\hline & Peronospora pulveracea & 1 & 100 & FJ384778 \\
\hline & Wallemia sebi & 1 & 100 & AM159621 \\
\hline & Peniophora cinerea & 1 & 100 & GU062269 \\
\hline & Pichia membranifaciens & 1 & 98 & FM178293 \\
\hline & Colleotothricum gloesporoides & 1 & 100 & HQ645079 \\
\hline & Galactomyces sp. & 1 & 100 & DQ286062 \\
\hline & Cryptococcus sp & 1 & 100 & JQ327851 \\
\hline & Rhodotorula sp & 1 & 99 & DQ643075 \\
\hline & Trichosporon sp & 1 & 100 & $J \times 270559$ \\
\hline & Phoma sp. & 1 & 100 & JF912667 \\
\hline \multirow[t]{16}{*}{$\mathrm{D} 1 / \mathrm{D} 2$} & Kluyveromyces marxianus group 1 & $3^{a}$ & 100 & HQ436414 \\
\hline & Kluyveromyces marxianus group 2 & $1+2^{a}$ & 100 & HQ396523 \\
\hline & Kluyveromyces marxianus group 3 & $2^{a}$ & 100 & FJ896141 \\
\hline & Debaryomyces hansenii & $2^{a}$ & 100 & HE681104 \\
\hline & Galactomyces geotrichum & $1^{\mathrm{a}}$ & 100 & JX649971 \\
\hline & Candida pararugosa & $1^{\mathrm{a}}$ & 100 & $A B 741061$ \\
\hline & Candida catenulata & $1^{\mathrm{a}}$ & 100 & FJ627977 \\
\hline & Candida glaebosa & 1 & 99 & EU327105 \\
\hline & Candida parapsilopsis & $1^{\mathrm{a}}$ & 100 & $A B 741061$ \\
\hline & Pichia subpelluculosa & 1 & 100 & JQ419793 \\
\hline & Torulaspora delbrueckii & $1^{\mathrm{a}}$ & 98 & HE799671 \\
\hline & Pachyphloeus virescens & 1 & 100 & EU543198 \\
\hline & Euroticum amstelodami & $1^{\mathrm{a}}$ & 100 & AY213699 \\
\hline & Exophiala dermatitidis & $1^{a}$ & 100 & JN391399 \\
\hline & Priceomyces carsonii & $1^{\mathrm{a}}$ & 95 & JX456534 \\
\hline & Uncultured soil fungus $^{\mathrm{b}}$ & $1^{\mathrm{a}}$ & 87 & JQ311712 \\
\hline \multirow[t]{3}{*}{ TUB } & Ophiocordyceps oxycephala & 1 & 100 & EU604145 \\
\hline & Alternaria solani & 1 & 100 & JQ672057 \\
\hline & Exophiala pisciphila & 2 & 97 & JN112495 \\
\hline
\end{tabular}

${ }^{a}$ Obtained by direct sequencing.

${ }^{b}$ Sequences deposited in the database. 
in-del do not lead to significant changes in the stemloop structure of the domain, that appears to have a conserved secondary structure in all the described variants (secondary structures not shown).

\section{Discussion}

Mountainsides have often been the subject of biodiversity and biogeography studies, with several papers focused on changes of microbial diversity with elevation (Singh et al. 2012; Wang et al. 2012). On the other hand, altitude has been demonstrated to be among the pasture-specific features that more deeply influence cheese characteristics (Martin et al. 2005). The present paper combines these aspects by exploring the diversity of fungal consortia inhabiting cow raw milk sampled at different altitudes in Alpine valleys of Valle d'Aosta region and used for producing the Fontina PDO cheese. To this aim, we performed a multilocus sequencing at barcodes commonly in use for the identification of fungal species, integrated by an intermediate cloning step when necessary. This allowed to detect also rarer species thus enriching the spectrum of observations, and to resolve multiple band patterns.

In addition to fungi, the used barcodes reproducibly identified a well-defined group of bacterial, plant and metazoan sequences. Bacterial sequences were retrieved by all the barcodes in 16 different milk samples. The more represented bacteria resulted the environmental species Escherichia coli, Enterobacter cloacae, and Macrococcus caseolyticus, already isolated from cow's milk and organs and from food-processing factories (Baba et al. 2009). Plants sequences were identified by ITS1 and TUB in 10 milk samples and mainly referred to grasses used to feed animals (Lolium multiflorum, $L$. perenne), flowering plants (e.g., Achillea wilsoniana, Dactylis glomerata), and wheat (Triticum turgidum). Finally, a sequence belonging to the cnidarian species Chromonephthea franseni was retrieved in 4 milks by ITS1. Alimentation and beverage are the plausible origins for all these sequences that have been retrieved in milks sampled at all altitudes. These results reflect known characteristics of most barcodes, especially the ribosomal ones. For example, ITS2, even if designed on fungal DNA, has proven to be effective for the identification of both plants and animals species and as such has been suggested as a possible "universal barcode" (Yao et al. 2010).

The fungal species detected in the analyzed raw milks are 31, in addition to 5 unresolved genera and a new sequence. ITS1 identified the majority of them, followed by D1/D2 and TUB. A short description of known sources and significance is provided in Table 1. Most species are yeasts, followed by moulds and by 2 macroscopic fungi (Psathyrella lutensis and the truffle
Pachyphloeus mosseae). Among yeasts, it is worth mentioning two species of black or "melanized" yeasts belonging to the genus Exophiala. Black yeasts are stress-tolerant microorganisms, adapted to extreme habitats (Cantrell et al. 2011) and the subject of growing biotechnological and medical interest (Gunde-Cimerman et al. 2011). Some species have recently been reported in meat-processing facilities (Thanh et al. 2012) and in food as tropical fruit (Sudhadham et al. 2008) and cheese (Panelli et al. 2012). The genus Exophiala, composed by thermo- and acidotolerant species, is a common inhabitant of many indoor and outdoor environments, especially of water, wet niches and forests. Exophiala dermatitidis, identified in a milk sampled at the bottom of valleys, has been recognized as the cause of infections in otherwise healthy patients in some tropical regions of South-Western Asia (Sudhadham et al. 2008).

The majority of the identified yeast species are common and known inhabitants of the dairy environment that play key roles in cheese-making processes thanks to their physiological and biochemical features (Jacques \& Casaregola 2008). Among these, K. marxianus resulted the most abundant species in the Alpine raw milks and was retrieved at all the altitudes, even if the 3 sequence variants identified by D1/D2 seemed to have a more "clustered" distribution. This yeast is common in raw milk (Fleet 2007). It is also a predominant species in cheeses, both in those made from raw milk (Bai et al. 2010; El-Sharoud et al. 2009; Laurenčic et al. 2008) where it often dominates the yeast mycoflora, and in those produced using pasteurized milk (Giannino et al. 2011; Welthagen \& Viljoen 1998; Welthagen \& Viljoen 1999).

Other species that we found with minor frequency in the Alpine raw milk ecosystem comprehend $D$. hansenii, Torulaspora delbrueckii, C. incospicua, C. pararugosa, C. glaebosa, G. geothricum, P. subpelliculosa, all of which already reported in milk (Borelli et al. 2006; Jacques \& Casaregola 2008). Another group is constituted by $C$. catenulata, C. parapsilopsis, P. membranifaciens, A. versicolor, and Yarrowia lipolytica, Clavispora lusitanae, Rhodotorula spp., Trichosporon spp., Phoma spp., Cryptococcus spp., already reported in various cheeses (Bai et al. 2010; Hocking \& Faedo 1992; Jacques \& Casaregola 2008; Montagna et al. 2004; Vasdinyei \& Deak 2003; Viljoen \& Greyling 1995; Welthagen \& Viljoen 1999). Candida spp. was the most represented genus, with 6 different species the majority of which (6 over 8 observations) found at altitudes $\geq 1800 \mathrm{~m}$.

Interestingly, one of the more abundant species, the environmental ascomycetous A. lineata (retrieved in 6 milks sampled at 1400 and $1800 \mathrm{~m}$ ) has never been put in relation with food nor with the dairy ecosystem. It is a salt-tolerant food decomposer, inhabitant of saltmarsh areas of South-Eastern USA where it is found in 
association to the plant Juncus roemerianus (Kohlmeyer \& Volkmann-Kohlmeyer 1993). To our knowledge, this is the first report of this species outside North-America. Its geographical distribution and ecology need to be updated as well as its possible roles in relation to human alimentation.

Finally, other species have never been reported in milk and are in general environmental fungi. Many of them result associated with plants: pathogens (e.g., Colletothricum gloesporioides, Alternaria solani, Macrophomina phaseo lina, Peronospora pulveracea), mutualistic symbionts that form arbuscular mychorrhizae (Funneliformis mossae), or fungi retrieved in dust, soil, wood etc. (A. penicilloides, Wallemia sebi, Peniophora cinerea, Euroticum amsteloda mi, Macrophomina phaseolina).

In summary, the fungal community of raw milk sampled on Alpine highlands pastures from Valle d'Aosta appears composed by many species of diverse environmental origin and significance, several of which never reported in milk. The most abundant resulted the dairy yeast $K$. marxianus and the ascomycetous $A$. lineata along with the Candida genus. The highest sampled altitude $(2200 \mathrm{~m})$ resulted rich in fungal diversity (17 species vs. 8 at $1800 \mathrm{~m}$, with similar numbers of sampled individual pastures). This observation reflects what previously reported (Singh et al. 2012). These authors observed a "peak" in bacterial diversity at around $2500 \mathrm{~m}$ when sampling soil at elevation intervals from $1000 \mathrm{~m}$, and explained these results on the basis of the coincidence with the precipitation maximum that reduces UV and prevents drying of soil, thus increasing bacterial diversity.

\section{Conclusions}

The work presented here enlarges the knowledge of fungal diversity in a primary alimentary matrix as raw milk. For the first time a microbial ecology study in the dairy field is performed with a focus on pasture altitude. On the other hand, for the first time, microbial ecology is included among factors, in the composition of Alpine pastures, that have the potential to shape the properties of milks and cheeses from animals grazing highland pastures, together with the already described physical, chemical and botanical variables (Buchin et al. 1999; Martin et al. 2005).

\section{Competing interests}

The authors declare that they have no competing interest.

\section{Authors' contributions}

MF ideated the experimental design, organized the sampling plan in Alpine valleys in accord with breeders and extracted the DNA from milk. SP and EB carried out the remaining practical work (PCR and sequencing). SP performed the bioinformatics analyses. SP and MF drafted the manuscript. All authors read and approved the final manuscript.
Received: 24 May 2013 Accepted: 15 August 2013

Published: 27 August 2013

\section{References}

Ai HL, Zhang LM, Chen YP, Zi SH, Xiang H, Zhao DK, Shen Y (2012) Two new compounds from an endophytic fungus Alternaria solani. J Asian Nat Prod Res 14:1144-1148

Baba T, Kuwahara-Arai K, Uchiyama I, Takeuchi F, Ito T, Hiramatsu K (2009) Complete genome sequence of Macrococcus caseolyticus strain JSCS5402, reflecting the ancestral genome of human-pathogenic Staphylococci. J Bacteriol 191:1180-1190

Bai M, Qing M, Guo Z, Zhang Y, Chen X, Bao Q, Zhang H, Sun TS (2010) Occurrence and dominance of yeast species in naturally fermented milk from the Tibetan Plateau of China. Can J Microbiol 56:707-714

Begerow D, Nilsson H, Unterseher M, Maier W (2010) Current state and perspectives of fungal DNA barcoding and rapid identification procedures. Appl Micriobiol Biotechnol 87:99-108

Beresford TP, Fitzsimons NA, Brennan NL, Cogan TM (2001) Recent advances in cheese microbiology. Int Dairy J 11:259-274

Borelli BM, Ferreira EG, Lacerda ICA, Franco GR, Rosa CA (2006) Yeast populations associated with the artisanal cheese produced in the region of Serra da Canastra, Brazil. World J Microbiol Biotechnol 22:1115-1119

Buchin S, Martin B, Dupont D, Bornard A, Achilleos C (1999) Influence of the composition of Alpine highland pastures on the chemical, rheological and sensory properties of cheese. J Dairy Res 66:579-588

Butinar L, Santos S, Spencer-Martins I, Oren A, Gunde-Cimerman N (2005) Yeast diversity in hypersaline habitats. FEMS Microbiol Lett 244:229-234

Cai L, Hyde KD, Taylor PWJ, Weir BS, Waller JM, Abang MM, Zhang JZ, Yang YL, Phoulivong S, Liu ZY, Prihastuti H, Shivas RG, McKenzie EHC, Johnston PR (2009) A polyphasic approach for studying Colletotrichum. Fungal Diversity 39:183-204

Cantrell SA, Dianese JC, Fell J, Gunde-Cimerman N, Zalar P (2011) Unusual fungal niches. Mycologia 103:1161-1174

Chamuris GP (1991) Speciation in the Peniophora cinerea complex. Mycologia 83:736-742

Corbo MR, Lanciotti R, Albenzio M, Sinigaglia M (2001) Occurrence and characterization of yeasts isolated from milks and dairy products of Apulia region. Int J Food Microbiol 69:147-152

De Rijk P, Van de Peer Y, De Wachter R (1997) Database on the structure of large ribosomal subunit RNA. Nucl Acids Res 25:117-122

El-Sharoud WM, Belloch C, Peris D, Querol A (2009) Molecular identification of yeasts associated with traditional Egyptian dairy products. J Food Science 74:341-346

Figel IC, Marangoni PR, Tralamazza SM, Vicente VA, do Rocio Dalzoto P, do Nascimento MM, de Hoog GS, Pimentel IC (2013) Black yeasts-like fungi isolated from dialisi water in hemodialysis units. Mycopathologia 175:413-420

Filtenborg O, Frisvad JC, Thrane U (1996) Moulds in food spoilage. Int J Food Microbiol 33:85-102

Fleet GH (2007) Yeasts in food and beverages: impact on product quality and safety. Curr Opin Biotech 18:170-175

Giammarco GM, Melilli D, Pizzo G (2004) Candida pararugosa isolation from the oral cavity o fan Italian denture beare. Res Microbiol 155:571-574

Giannino ML, Marzotto M, Dellaglio F, Feligini M (2009) Study of microbial diversity in raw milk and fresh curd used for Fontina cheese production by culture-independent methods. Int J Food Microbiol 130:188-195

Giannino ML, Buffoni JN, Massone E, Feligini M (2011) Internal transcribed spacer as a target to assess yeast biodiversity in ItalianTaleggio PDO cheese. J Food Science 76:511-514

Giraud F, Giraud T, Aguileta G, Fournier E, Samson R, Cruaud C, Lacoste S, Ropars J, Tellier A, Dupont J (2010) Microsatellite loci to recognize species for the cheese starter and contaminating strains associated with cheese manufacturing. Int J Food Microbiol 137:204-213

Glass NL, Donaldson GC (1995) Development of primer sets for use with PCR to amplify PCR conserved genes from filamentous Ascomycetes. Appl Environm Microbiol 61:1323-1330

Gőker M, Blásquez-García G, Voglmayr H, Tellería MT, Martín MP (2009) Molecular taxonomy of phytopathogenic fungi: a case study in Peronospora. Plos One 4:e6139

Gunde-Cimerman N, Grube M, de Hoog GS (2011) The emerging potential of melanized fungi: black yeasts between beauty and the beast. Fungal Biol 115:935-936 
Hall TA (1999) BioEdit: a user-friendly biological sequence alignment editor and analysis program for Windows 95/98/NT. Nucl Acids Symp Series 41:95-98

Hatoum R, Labrie S, Fliss I (2012) Antimicrobial and probiotic properties of yeasts: from fundamental to novel applications. Frontiers Microbiol 3:1-12

Heinrich G, Hübner I, Schmidt CK, de Hoog GS, Haase G (2013) Analysis of black fungal biofilms occurring at domestic water taps (I): compositional analysis using Tag-encoded FLX amplicon pyrosequencing. Mycopathologia 175:387-397

Hocking AD, Faedo M (1992) Fungi causing thread mould spoilage of vacuum packaged Cheddar cheese during maturation. Int J Food Microbiol 16:123-130

Itabashi T, Matsuishi N, Hosoe T, Toyazaki N, Udagawa S, Imai T, Adachi M, Kawai K (2006) Two new dioxopiperazine derivatives, arestrictins A and B, isolated from Aspergillus restrictus and Aspergillus penicilloides. Chem Pharm Bull 54:1639-1641

Jacques N, Casaregola S (2008) Safety assessment of dairy yeasts: the hemiascomycetous yeasts. Int J Food Microbiol 126:321-326

Knutsen AK, Robert V, Poot GA, Epping W, Fiffe M, Holst-Jensen A, Skaar I, Smith MT (2007) Polyphasic re-examination of Yarrowia lipolytica strains and the description of three novel Candida species: Candida osloniensis sp. nov., Candida alimentaria sp. nov and Candida hollandica sp. nov. Int J Syst Evol Microbiol 57:2426-2435

Kohlmeyer J, Volkmann-Kohlmeyer B (1993) Atrotorquata and Loratospora: new ascomycete genera on Juncus roemerianus. Syst Ascom 12:7-22

Kumar S, Tamura Z, Nei M (2004) MEGA3: an integrated software for molecular evolutionary genetics analysis and sequence alignment. Briefings Bioinf 5:150-163

Kurtzmann CP, Robnett CJ (1997) Identification of clinically important ascomycetous yeasts based on nucleotide divergence in the $5^{\prime}$ end of the large-subunit (26S) ribosomal DNA gene. J Clin Microbiol 35:1216-1223

Lane MM, Morrisey JP (2009) Kluyveromyces marxianus: a yeast emerging from its sister's shadow. Fung Biol Rev 24:17-26

Larsson E, Örstadius L (2008) Fourteen coprophilus species of Psathyrella identified in the Nordic countries using morphology and nuclear rDNA sequence data. Mycol Res 112:1165-1185

Laurenčic M, Sulo P, Sláviková E, Piecková E, Seman M, Ebringer L (2008) The diversity of eukaryotic microbiota in the traditional Slovak sheep cheese bryndza. Int J Food Microbiol 127:176-179

Lund F, Filtenborg O, Frsvad JC (1995) Associated mycobiota of cheese. Food Microbiol 12:173-180

Martin B, Verdier-Metz I, Buchin S, Hurtaud C, Culon JB (2005) How do the nature and pasture diversity influence the sensory quality of livestock products? Anim Science 81:205-212

Montagna MT, Santacroce MP, Spilotros G, Napoli C, Minervini F, Papa A, Dragoni I (2004) Investigation of fungal contamination in sheep and goat cheeses in southern Italy. Mycopathologia 158:245-249

Nakagawa Y, Robert V, Kawarazaki J, Epping W, Smith MT, Poot GA, Mizuguchi I, Kanbe T, Doi M (2004) Recurrent isolation of an uncommon yeast, Candida pararugosa, from a sarcoma patient. Med Mycol 42:267-271

Panelli S, Buffoni JN, Bonacina C, Feligini M (2012) Identification of moulds from the Taleggio cheese environment by the use of DNA barcodes. Food Control 28:385-391

Radosavljevic M, Koenig H, Letscher-Bru V, Waller J, Maloisel F, Lioure B, Herbrecht R (1999) Candida catenulata fungemia in a cancer patient. J Clin Microbiol 37:475-477

Rakeman JL, Bui U, LaFe K, Chen Y-C, Honeycutt RJ, Cookson BT (2005) Multilocus DNA sequence comparisons rapidly identify pathogenic moulds. J Clin Microbiol 43:3324-3333

Singh D, Takahashi K, Kim M, Chun J, Adams JM (2012) A Hump-backed trend in bacterial diversity with elevation on Mount Fuji, Japan. Microb Ecol 63:429-437

Sudhadham M, Sihanonth P, Sivichai S, Chaiyarat R, Dorrestein GM, Menken SBJ, de Hoog GS (2008) The neurotrophic black yeast Exophiala dermatitidis has a possible origin in the tropical rain forest. Studies Mycol 61:145-155

Thanh VN, Hai DA, Hien DD, Takashima M, Lachance MA (2012) Moniliella carnis sp. nov. and Moniliella dehoogii sp. nov., two novel species of black yeasts isolated from meat processing environments. Int J Syst Evol Microbiol 62:3088-3094

Torres-Rodríguez JM, Madrenys-Brunet N, Siddat M, López-Jodra O, Jimenez T (1998) Aspergillus versicolor as cause of onychomycosis: report of 12 cases and susceptibility testing to antifungal drugs. JEADY 11:25-31

Vasdinyei R, Deak T (2003) Characterization of yeast isolates originating from Hungarian dairy products using traditional and molecular identification techniques. Int J Food Microbiol 86:123-130
Viljoen BC, Greyling T (1995) Yeast associated with Cheddar and Gouda making. Int J Food Microbiol 28:79-88

Wang J, Soininen J, He J, Shen J (2012) Phylogenetic clustering increases with elevation for microbes. Environm Microbiol Rep 4:217-226

Welthagen JJ, Viljoen BC (1998) Yeast profile in Gouda cheese during processing and ripening. Int J Food Microbiol 41:185-194

Welthagen JJ, Viljoen BC (1999) The isolation and identification of yeasts obtained during the manufacture and ripening of Cheddar cheese. Food Microbiol 16:63-73

White TJ, Bruns T, Lee S, Taylor J (1990) Amplification and direct sequencing of fungal ribosomal RNA genes for phylogenetics. In: Innis MA, Gelfand DH, Sninsky JJ, White TJ (eds) PCR protocols: a guide to methods and applications Academic Press Inc, San Diego, pp 315-322

Yao H, Song J, Liu C, Luo K, Han J, Li Y, Pang X, Xu H, Zhu Y, Xiao P, Chen S (2010) Use of ITS2 region as the universal DNA barcode for plants and animals. Plos One 5:e13102

doi:10.1186/2193-1801-2-405

Cite this article as: Panelli et al: Diversity of fungal flora in raw milk from the Italian Alps in relation to pasture altitude. SpringerPlus 2013 2:405.

\section{Submit your manuscript to a SpringerOpen ${ }^{\circ}$ journal and benefit from:}

- Convenient online submission

- Rigorous peer review

- Immediate publication on acceptance

- Open access: articles freely available online

- High visibility within the field

- Retaining the copyright to your article

Submit your next manuscript at springeropen.com 